Abstracta Iranica

Revue bibliographique pour le domaine irano-aryen

Volume 34-35-36 | 2017

Comptes rendus des publications de 2011-2013

\title{
Niccolò Manassero. Tamga-like images on sealings from Old Nisa
}

\section{Rémy Boucharlat}

\section{(2) OpenEdition}

10 Journals

Édition électronique

URL : http://journals.openedition.org/abstractairanica/42280

DOI : 10.4000/abstractairanica.42280

ISSN : 1961-960X

\section{Éditeur :}

CNRS (UMR 7528 Mondes iraniens et indiens), Éditions de l'IFRI

\section{Référence électronique}

Rémy Boucharlat, " Niccolò Manassero. Tamga-like images on sealings from Old Nisa », Abstracta Iranica [En ligne], Volume 34-35-36 | 2017, document 27, mis en ligne le 30 juillet 2017, consulté le 02 octobre 2020. URL : http://journals.openedition.org/abstractairanica/42280 ; DOI : https://doi.org/10.4000/ abstractairanica. 42280

Ce document a été généré automatiquement le 2 octobre 2020.

Tous droits réservés 


\title{
Niccolò Manassero. Tamga-like images on sealings from Old Nisa
}

\author{
Rémy Boucharlat
}

\section{RÉFÉRENCE}

Niccolò Manassero. « Tamga-like images on sealings from Old Nisa ». Parthica, 12, 2010 [2011], p. 17-29.

1 Les fouilles italo-turkmènes de Nisa ont produit 91 bulles (au sens large, scellements inclus) provenant principalement de deux salles du bâtiment occupant l'angle so de l'enceinte. Elles s'ajoutent aux quelque 70 bulles trouvées à l'époque soviétique dans le "Square House ». La plupart sont des scellements de jarres (khums), ou de sacs, ou encore de portes mais aucune n'était attachée à un document écrit. L'A. étudie sept de ces objets dont le sujet unique est une sorte de tamga, un objet noué au milieu avec une boucle d'un côté et deux extrémités libres. Il n'y a pas un modèle unique mais les nombreuses variantes n'offrent pas de comparaison directe avec des exemples dans le monde parthe d'Asie centrale où ce type de symbole est en général secondaire, accompagnant un sujet principal. Comme le suggère l'A. faut-il y voir un attribut royal ou divin?

\section{AUTEURS}

RÉMY BOUCHARLAT

UMR 5133 CNRS-Université de Lyon 